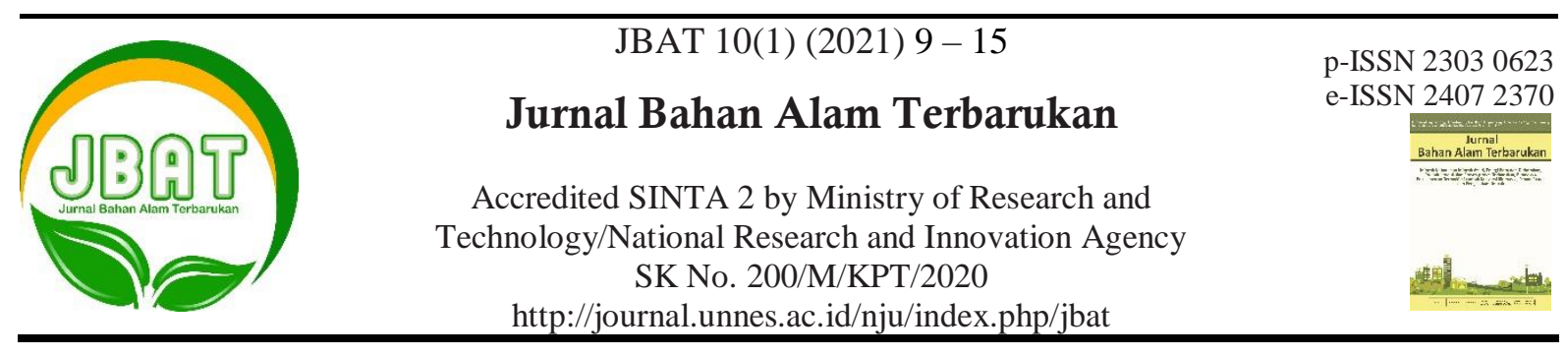

\title{
Potential of Energy Municipal Solid Waste (MSW) to Become Refuse Derived Fuel (RDF) in Bali Province, Indonesia
}

\author{
I Wayan Koko Suryawan ${ }^{1, \bowtie,}$ I Made Wahyu Wijaya ${ }^{2,}$ Novi Kartika Sari ${ }^{3}$, Iva Yenis \\ Septiariva ${ }^{4}$, Nurulbaiti Listyendah Zahra ${ }^{1}$
}

\section{DOI: https://doi.org/10.15294/jbat.v10i1.29804}

${ }^{1}$ Department of Environmental Engineering, Faculty of Infrastructure Planning, Universitas Pertamina, Komplek Universitas Pertamina, Jalan Sinabung II, Terusan Simprug, Jakarta 12220, Indonesia

${ }^{2}$ Postgraduate Program of Regional Development Planning and Environmental Management, Universitas Mahasaraswati, Denpasar, 80233, Indonesia

${ }^{3}$ Environmental Engineering Study Program, Jurusan Teknologi Infrastruktur dan Kewilayahan, Institut Teknologi Sumatera, J1. Terusan Ryacudu, Way Huwi, Kec. Jati Agung, Kabupaten Lampung Selatan, Lampung 35365, Indonesia

${ }^{4}$ Sanitary Engineering Laboratory, Study Program of Civil Engineering, Faculty of Engineering, Universitas Sebelas Maret, Jalan Ir Sutami 36A, Kentingan, Surakarta, Indonesia emistry Department, D3 Pharmacy, Sekolah Tinggi Ilmu Farmasi Nusaputera, Indonesia

\begin{tabular}{|c|c|}
\hline Article Info & Abstract \\
\hline $\begin{array}{l}\text { Article history: } \\
\text { Received } \\
\text { April } 2021 \\
\text { Accepted } \\
\text { June } 2021 \\
\text { Published } \\
\text { June } 2021 \\
\text { Keywords: } \\
\text { RDF; } \\
\text { MSW; } \\
\text { renewable } \\
\text { energy; } \\
\text { GHG }\end{array}$ & $\begin{array}{l}\text { The generation of municipal solid waste (MSW) in Bali has various environmental impacts. } \\
\text { One of the updates on sustainable waste processing is the RDF treatment plant processing. } \\
\text { Before carrying out the processing, MSW characterization is needed because each region has } \\
\text { a diverse composition. The processing of MSW into RDF provides benefits for achieving } \\
\text { MSW reduction targets, renewable energy use, and the reduction of greenhouse gas (GHG) } \\
\text { emissions. For this reason, this study was conducted to determine the potential of MSW in } \\
\text { Bali as an alternative to renewable fuel and its potential to reduce GHG. MSW's potential } \\
\text { calorific value as a raw material for RDF in Bali can reach } 9.58-17.71 \mathrm{MJ} / \mathrm{kg} \text {. The } \\
\text { implementation of processing waste into RDF in pellets has shown a calorific value of } \pm 3904 \\
\text { - } 4945 \mathrm{kkcal} / \mathrm{kg} \text {. Implementing MSW processing into RDF in Bali can reduce GHG by } 178 \\
\text { - } 330 \text { times compared to open dumping. }\end{array}$ \\
\hline
\end{tabular}

\section{INTRODUCTION}

Bali is an international tourist destination, so cleanliness and beauty are an absolute requirement in tourism. The provincial government of Bali issued a policy of Bali Governor Regulation number 97 of 2018 concerning restrictions on the generation of single-use plastic waste. In line with the government's commitment to provide electricity to all corners of the country and achieve the target of using renewable energy of $23 \%$ by 2025 and $31 \%$ by 2050 (Peraturan Pemerintah Indonesia, 2014). The minimal use of renewable energy for electricity is due to the relatively high production price of New, Renewable Energy (NRE)-based power plants, making it difficult to compete with fossil plants. Besides, the lack of support from the domestic industry related to renewable energy generation components and the difficulty of obtaining funding are also obstructions to renewable energy development. One of the successful strategies to support these two things is the Local Waste Processing (Tempat Olah Sampah Setempat) (TOSS) program (Legino et al., 2019). The implementation of TOSS is currently only carried out in Klungkung Regency. This waste

\footnotetext{
Corresponding author:

E-mail: i.suryawawan@universitaspertamina.ac.id
} 
processing product is in the form of $\mathrm{RDF}$ in the form of pellets or briquettes.

RDF results from a waste separation process between fractions of flammable and noncombustible waste such as metal and glass. RDF production is part of a thermal treatment system that aims to valorize part of the waste stream by restoring energy content (Cheremisinoff et al., 2003). Various compositions of MSW can be burned without additional fuel. Fuel from biomass is highly dependent on the binder process and moisture content (Borowski et al., 2013). However, since water and non-combustible materials do not increase the calorific value of the waste minimizing moisture content and reducing ash content can significantly improve fuel quality and increase combustion efficiency. One of the successes of waste management depends on the waste characterization process. Waste characterization can come from physical properties, such as the composition of waste, particle size, moisture content, density, ultimate results, calorific value, ash content, volatile content, and metal parameters.

RDF's utilization is expected to reduce land, reduce GHG emissions, and reduce water bodies' pollution by leachate from landfills. However, the use of RDF to date has not shown encouraging results. The readiness of regions that directly manage waste is still discussed on how waste becomes an alternative energy source or fuel. Waste management in several areas in Bali is still conventional or open dumping and has the potential to pollute the environment. Emissions released from the open dumping process can contribute to GHG emissions (Rafiq et al., 2018).

By processing MSW into $\mathrm{RDF}$, it will indirectly reduce the impact of GHG. As a basis for planning waste processing with the RDF plant, it is necessary to characterize the fuel based on the composition of MSW. The main characteristic required is the energy potential in MSW. For this reason, the study aims to determine the potential characteristics of the RDF from MSW in Bali and to estimate $\mathrm{CO}_{2}$ emissions from processing into $\mathrm{RDF}$ and open dumping.

\section{MATERIALS AND METHODS}

\section{Materials}

This research was conducted in six different city locations, namely Tabanan, Semarapura, Singaraja, Bangli, Denpasar, and
Amlapura (Figure 1). In this study, the categories of waste composition used as a benchmark for waste characteristics are food waste, garden waste, paper, plastic, metals, textile, rubber, glass, and others. Waste composition data were obtained from the National Waste Information System/Sistem Informasi Sampah Nasional (SIPSN) from 2017 2018 (Kementerian Lingkungan Hidup dan Kehutanan Republik Indonesia, 2020).

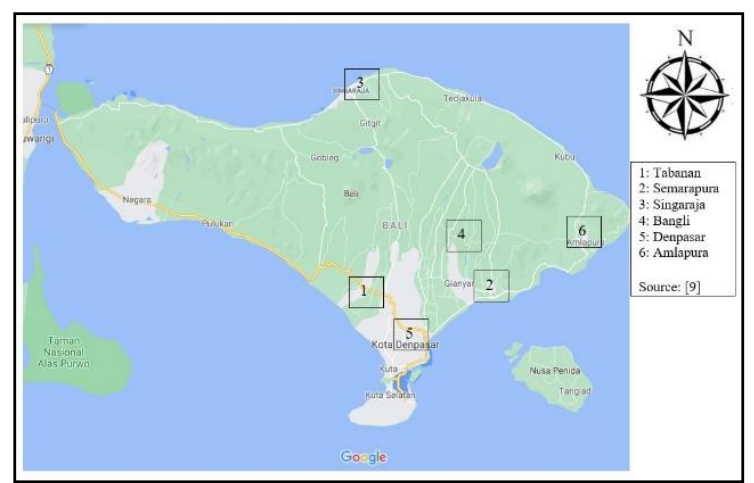

Figre 1. Research locations to determine the energy potential in MSW (Google Map, 2020).

\section{Energy Potential Calculation}

The calculation of the theoretical calorific value in this study was used from the previous research literature, which researched Bali waste's calorific value. In calculating the theoretical calorific value (Table 1), statistical data are taken to calculate the energy content using the proximate analysis of the Tchobanoglous et al. (1993) model listed in Eq. (1).

Calorific Value Potential heating value $=$ waste generation rate $(\mathrm{dm} / \mathrm{t}) \mathrm{x}$ reference heating value $(\mathrm{MJ} / \mathrm{kg})$

Table 1. Calorific value for each category of waste composition in Bali (Gunamantha, 2010).

\begin{tabular}{lc}
\hline Waste category & Caloric Value $(\mathrm{MJ} / \mathrm{kg})$ \\
\hline Food Waste & 3.86 \\
Garden Waste & 10.87 \\
Paper & 13.51 \\
Plastic & 36.38 \\
Textile & 15.35 \\
Rubber & 19.97 \\
\hline
\end{tabular}

\section{$\mathrm{CO}_{2}$ Emission}

Estimates of the amount of $\mathrm{CO}_{2}$ emitted from waste processing were compared in this study. The first scenario is waste processing using RDF 


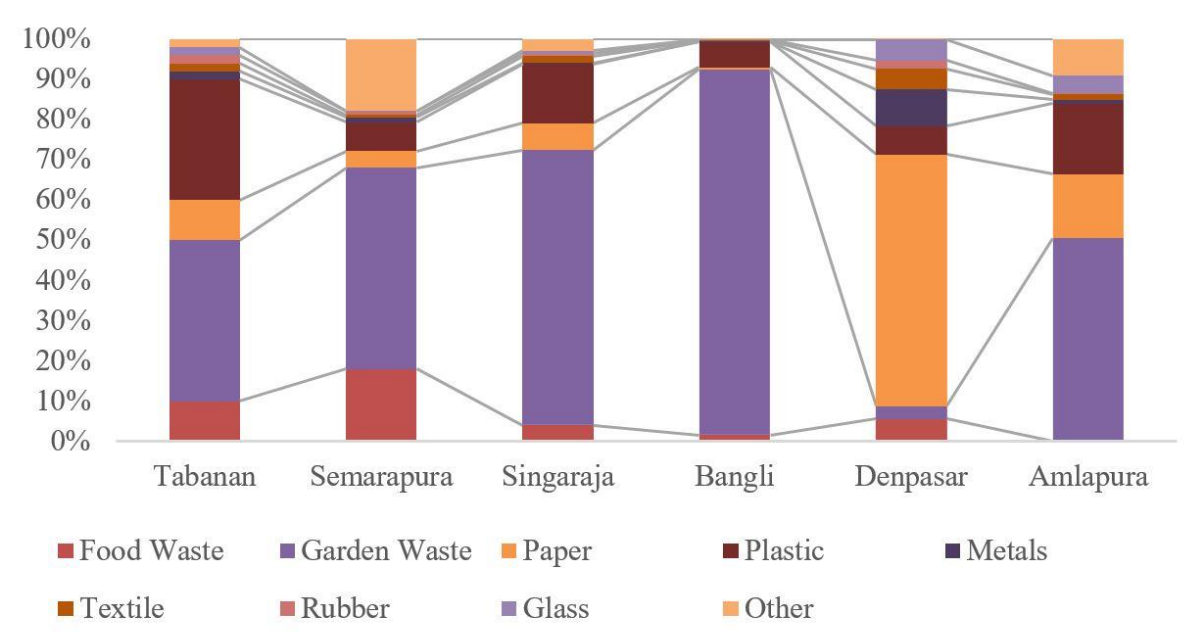

Figure 2. Composition of MSW in cities of Bali

and the second scenario is waste processing using landfills. The calculation of $\mathrm{CO} 2$ emissions for each scenario uses Eq. (2). Emission factors are determined based on research and are very specific for each material or product. Waste processing into $\mathrm{RDF}$ uses an emission factor of $94.8 \mathrm{tCO}_{2} / \mathrm{TJ}$ (Yun et al., 2007). Meanwhile, landfill processing emissions an emission factor of 300.000-gram $\mathrm{CO}_{2}$ /T (Zaman, 2010; DEFRA, 2007).

\section{$\mathrm{CO}_{2}$ Emission $=$ Activity data $\mathrm{x}$ Emission Factor}

\section{Data Collection}

The field survey was carried out to find out how to treat existing waste into RDF. Field surveys were also conducted with the management. The results of the field survey in this study will be discussed descriptively. Measurement of pellet characteristics based on proximate and ultimate tests. The proximate test was carried out by gravimetric method with ASTM E790-87 (2004) and ASTM E830-87 (2004) standards. The ultimate analysis is carried out by elemental analysis. Physical analysis of pellets was carried out with hardness parameters with a Shore D durometer (Sauter HBD 100-0) measuring instrument based on ASTM D2240 measurements.

\section{RESULTS AND DISCUSSION}

\section{MSW Composition}

The composition of MSW is obtained from sorting and weighing the selection results according to the type expressed as a percentage (\%). The largest composition of MSW waste is garden waste (except Denpasar), with a percentage of above $40 \%$ (Figure 2). Denpasar City has a high composition of paper waste compared to other cities in Bali Province. MSW such as plastic waste, paper waste, rubber waste, and textile are materials that can be burned (Anasstasia et al., 2020). The classification of waste based on its degradation phase is divided into three, namely slowly degradable (e.g., wood, rubber), moderate degradable (e.g., textiles), rapidly degradable (e.g., food waste), and non-degradable (e.g., metals) (Chakma and Mathur, 2007).

Bali Province's food waste is relatively low in urban areas compared to several cities in Indonesia (Triyono et al., 2018). Food waste is rarely used in waste to energy by thermal processing or $\mathrm{RDF}$ because of its low calorific value. Waste that contains a lot of biodegradable organic such as food waste is more suitable for composting (in aerobic processing) or with anaerobic digester to get biogas. Speeding waste containing wood has high enough organic matter and leaves a relatively low amount of ash. This type of waste has an opportunity in Bali because many traditional activities in Bali use plantation raw materials for ceremonies such as leaf leaves, wood, incense, leaves, and flowers. However, to improve RDF quality with organic waste, pre-processing applications such as natural and mechanical drying, preheating to evaporate water that is carried along with the waste, can be used and cutting to facilitate combustion.

\section{Potential RDF (Refuse-Derived Fuels)}

Based on Eq. (1), the resulting calorific value for each area results (Table 2) from municipal solid waste's heating value depending on the waste 


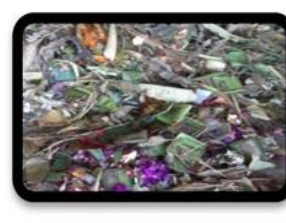

Raw MSW
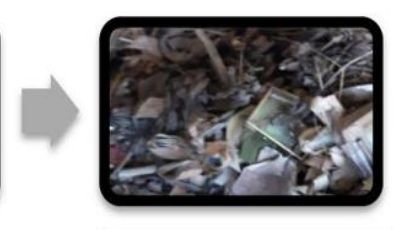

Pre-treatment Pre-treatment
(Bio drying)
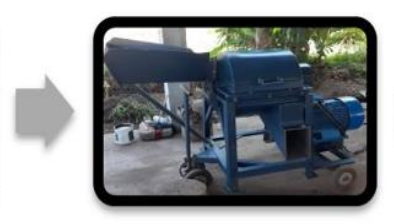

Shredded

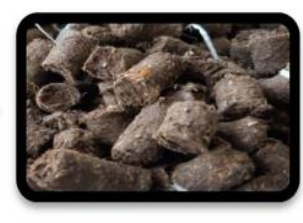

Pelletizing

Figure 3. The stages of processing waste into RDF in the form of pellets

composition. Although the total calorific value per capita in Semarapura City is higher than Tabanan City and Bangli City, the composition of inert waste as another material is relatively high, namely $17.91 \%$, causing the potential for MSW utilization in Semarapura City to below. Tabanan City has a potential utilization of MSW as RDF of 17.71 $\mathrm{MJ} / \mathrm{kg}$; the composition of plastic waste in this area is relatively high compared to other cities. Research in the Cilacap area located at Jeruklegi Landfill can potentially increase MSW treatment to RDF with a calorific value of $14.91 \mathrm{MJ} / \mathrm{kg}$ for 293,000 IDR/ton (Paramita et al., 2018). With this estimate, the calorific value for waste in Tabanan City can reach 368,016 IDR/ton.

Table 2. The potential caloric value of MSW in cities of Bali.

\begin{tabular}{lcc}
\hline Area & $\begin{array}{c}\text { Total } \\
\text { Caloric Value } \\
\text { (MJ/cap.day) }\end{array}$ & $\begin{array}{c}\text { Potential } \\
\text { Caloric } \\
\text { Value } \\
\text { (MJ/kg) }\end{array}$ \\
\hline Tabanan & 0.708 & 17.71 \\
Semarapura & 0.862 & 9.58 \\
Singaraja & 2.133 & 14.22 \\
Bangli & 0.740 & 12.34 \\
Denpasar & 7.148 & 12.76 \\
Amlapura & 1.714 & 14.28 \\
\hline
\end{tabular}

\section{Application RDF}

The application of waste to energy in the form of pellet-shaped RDF has been implemented in the Material Recovery Facility (MRF) in Semarapura City (Figure 3). The MSW used is in the form of mixed waste, which is then processed by bio drying. After bio drying for ten days, the waste can be chopped and then printed pellets with a diameter of $12 \mathrm{~mm}$. In pellet printing, a binder in the form of starch can be used. The type of starch binder has no effect on the quantity of RDF pellets produced (Borowski et al., 2017). Measurements made are based on survey results. These pellets can reach $\pm 3500 \mathrm{kkcal} / \mathrm{kg}$ or $\pm 14.64 \mathrm{MJ} / \mathrm{kg}$. The results showed an increase in organic waste; the highest caloric value of around $36 \mathrm{MJ} / \mathrm{kg}$ was obtained in RDF with $40 \%$ organic waste content (Dianda \& Munawar, 2018). Implementation of waste processing in Semarapura City, which is $1 \mathrm{~kg}$ of pellet, may produce around $1 \mathrm{kWh}$ of electrical energy (Legino et al., 2019). Pelletized waste is more comfortable to pack compared to transportation with MSW containers, which require compaction.

The processed pellets are then dried in the sun to reduce the moisture content in the pellets and indirectly increase the calorific value of the waste pellets. The drying process of the pellets uses an open tarpaulin with a maximum height of $10 \mathrm{~cm}$, this is done so that the drying process can occur properly. This sunlight drying process is also carried out to increase the hardness and caloric value of the pellets. The drying process can take 1-7 days.



Figure 4. Sundrying of Pellets

Table 3 shows the proximate and ultimate test results of pelletization results. The resulting moisture content and ash content show low values, and it can be said that it is suitable for fuel use. Gendebien et al. (2003) stated that the maximum moisture and ash content of an RDF in Italy is $25 \%$ 
and $20 \%$. As for the calorific value, it can also be said to be quite satisfying where the results show $3904 \mathrm{kkcal} / \mathrm{kg}$ or $16.34 \mathrm{MJ} / \mathrm{kg}$. It also meets the standards of the Italian State.

Table 3. The characteristic of RDF pellet

\begin{tabular}{lc}
\hline \multicolumn{1}{c}{ Parameters } & RDF characteristic \\
\hline Water content & $3.8 \%$ \\
Ash Content & $2.2 \%$ \\
$\mathrm{C}$ & $55.7 \%$ \\
$\mathrm{H}$ & $8.9 \%$ \\
$\mathrm{O}$ & $24.5 \%$ \\
$\mathrm{~N}$ & $2.3 \%$ \\
$\mathrm{~S}$ & $2.6 \%$ \\
Energy & $3904 \mathrm{kkcal} / \mathrm{kg}$ \\
Hardness (Shore D) & $64 \mathrm{HA}$ \\
\hline
\end{tabular}

In planning the RDF treatment plant, a particular study is needed for the raw materials' characteristics. Then the design is carried out in the form of providing alternative processing, determining the material balance of each alternative, determining the need for land and work area, energy supply needs, calculating the value product economics, and work operational standards. These steps need to be taken to produce a sustainable RDF treatment plant.

\section{Comparison of RDF and Landfill $\mathrm{CO}_{2}$ Emissions}

It can be seen in Table 4 that waste processing with far landfills produces $\mathrm{CO}_{2}$ emissions compared to waste utilization with $\mathrm{RDF}$. The utilization of waste into RDF can reduce $\mathrm{CO}_{2}$ emissions into the atmosphere 178 - 330 times. $\mathrm{RDF}$ is expected to minimise land for landfills, reduce GHG emissions from landfills, reduce coal use, and support environmentally friendly fuels and energy (Samosir, 2019). The benefits of using RDF include reducing raw materials and coal fuel, a nonrenewable energy source, and destroying and reducing waste. Besides, $\mathrm{RDF}$ can reduce $\mathrm{CO}_{2}$ emissions, both from production activities using coal and methane gas pollution from waste. The higher global warming impact of open dumping applications can be largely eliminated by implementing the suggested waste valorization (Maheshi, 2015).

The reduction of GHG impacts from the operational of energy-based waste management needs to be studied further. The current condition of urban waste in Bali Province tends to decrease during the COVID-19 pandemic condition (Suryawan et al., 2021). However, this condition will not have a permanent impact on sustainable development.

\section{CONCLUSION}

The lowest and highest potential heating value of MSW as a raw material for RDF in Bali is 9.58 and $17.71 \mathrm{MJ} / \mathrm{kg}$, respectively. Field application shows that processing waste into $\mathrm{RDF}$ in pellets can reach $\pm 14.64 \mathrm{MJ} / \mathrm{kg}$. The potential for GHG derived from MSW processing is 178 - 330 times.

\section{ACKNOWLEDGEMENT}

The authors would like to thank to TOSS of Klungkung to provide field observasion. We also thank to the reviewers and editors of this journal.

\section{REFERENCES}

Anasstasia, T. T., Lestianingrum, E., Cahyono, R. B., Azis, M. M. 2020. Life Cycle Assessment of Refuse Derived Fuel (RDF)

Table 4. Comparison of RDF and Landfill $\mathrm{CO}_{2}$ Emissions in Bali

\begin{tabular}{|c|c|c|c|}
\hline Area & $\begin{array}{c}\text { Waste } \\
\text { to landfill } \\
\text { (ton/day) }\end{array}$ & $\begin{array}{c}\mathrm{RDF} \\
\text { Scenario Emission } \mathrm{tCO}_{2} \text { eq/day }\end{array}$ & $\begin{array}{l}\text { Emission } \\
\mathrm{tCO}_{2} \mathrm{eq} / \text { day }\end{array}$ \\
\hline Tabanan & 18.08 & 30.35 & 5,424 \\
\hline Semarapura & 12.1 & 10.99 & 3,630 \\
\hline Singaraja & 102 & 137.47 & 30,600 \\
\hline Bangli & 13.26 & 15.51 & 3,978 \\
\hline Denpasar & 530.77 & 642.24 & 159,231 \\
\hline Amlapura & 50 & 67.70 & 15,000 \\
\hline
\end{tabular}


for Municipal Solid Waste (MSW) Management: Case Study Area Around Cement Industry, Cirebon, Indonesia. IOP Conference Series: Materials Science and Engineering. 778(1): 012146

Borowski, G., Hycnar, J. J. 2013. Utilization of fine coal waste as a fuel briquettes. International Journal of Coal Preparation and Utilization. 33(4): 194-204.

Borowski, G., Stępniewski, W., Wójcik-Oliveira, K. 2017. Effect of starch binder on charcoal briquette properties. International Agrophysics. 31(4): 571.

Chakma, S., Mathur, S. 2007. Settlement of MSW landfills due to biodegradation. Proceedings of the International Conference on Sustainable Solid Waste Management. 234-238.

Cheremisinoff, N. P. 2003. Handbook of solid waste management and waste minimization technologies. ButterworthHeinemann

DEFRA, 2007. Department for Environment, Food and Rural Affairs. Incineration of municipal solid waste, waste management technology brief, the new technologies work stream of the Defra Waste Implementation Programme,

Dianda, P., Munawar, E. 2018. Production and characterization refuse derived fuel (RDF) from high organic and moisture contents of municipal solid waste (MSW). IOP Conference Series: Materials Science and Engineering. 334(1): 012035.

Gendebien, A. 2003. Refuse derived fuel, current practice and perspectives. WRc Ref: CO5087-4.

Google Map, 2020. [Online]. Available: https://www.google.com/maps/@8.4318525,115.1198684,9.75z?hl=id.

[Accessed 0710 2020].

Gunamantha, M. 2010. Life Cycle Assessment Pada Sistem Pengelolaan Sampah Di Wilayah Sarbagita, Bali. Jurnal Purifikasi. 11(1): 41-52.

Kementerian Lingkungan Hidup dan Kehutanan Republik Indonesia, "Sistem Informasi Pengelolaan Sampah Nasional Diakses melalui sipsn.menlhk.go.id," 2020. [Online]. Available: http://sipsn.menlhk.go.id/?q=3a-

komposisi-sampah. [Accessed 0610 2020].

Legino, S., Hidayawanti, R., Wirantika, I. 2019. Waste as fastest cycle of renewable energy sources through TOSS Model. Journal of Physics: Conference Series. 1282(1): 012041.

Legino, S., Hidayawanti, R., Putra, I. S., Pribadi, A. 2019. Reducing coal consumption by people empowerment using local waste processing unit. Journal of Physics: Conference Series. 1217(1): 012028).

Maheshi, D. 2015. Environmental and economic assessment of 'open waste dump' mining in Sri Lanka. Resources, Conservation and Recycling. 102: 67-79.

Paramita, W., Hartono, D. M., Soesilo, T. E. B. 2018. Sustainability of Refuse Derived Fuel Potential from Municipal Solid Waste for Cement's Alternative Fuel in Indonesia (A Case at Jeruklegi Landfill, in Cilacap). IOP Conference Series: Earth and Environmental Science. 159(1): 012027.

Peraturan Pemerintah Indonesia, PP No. 79 Tahun 2014 tentang Kebijakan Energi Nasional, Jakarta: Peraturan Pemerintah Indonesia, 2014.

Rafiq, A., Rasheed, A., Arslan, C., Tallat, U., Siddique, M. 2018. Estimation of greenhouse gas emissions from Muhammad wala open dumping site of Faisalabad, Pakistan. Geology, Ecology, and Landscapes. 2(1): 45-50.

Samosir, A. P. 2019. Analisis Pemanfaatan Refuse Derived Fuel Sebagai Sumber Bahan Bakar Alternatif, Bogor: Penerbit IPB Press.

Suryawan, I. W. K., Rahman, A., Septiariva, I. Y., Suhardono, S., Wijaya, I. M. W. 2021. Life Cycle Assessment of Solid Waste Generation During and Before Pandemic of Covid-19 In Bali Province. Journal of Sustainability Science and Management. 16(1): 11-21.

Tchobanoglous, G., Theisen, H., Vigil, S. 1993. Integrated solid waste management: Engineering principles and management lssues. McGraw-Hill.

Triyono, B., Prawisudha, P., Mardiyati, M., Pasek, A. D. 2018. Experimental Study on Utilization of Indonesian Non-Recycled 
Organic Waste as Renewable Solid Fuel Using Wet Torrefaction Process. Engineering Journal. 22(6): 81-92.

Yun, S. K. 2007. Development of GHG emission factors for alternative fuels with assessment of emission reduction in cement industry. Graduate student good articles for United Nations Framework Convention on
Climate Change, the Korea Energy Management Corporation. 42-43.

Zaman, A. U. 2010. Comparative study of municipal solid waste treatment technologies using life cycle assessment method. International Journal of Environmental Science \& Technology. 7(2): 225-234. 